\title{
Open abdomen management: single institution experience
}

\section{Abdômen aberto: experiência em uma única instituição}

\author{
Adilson Costa Rodrigues Junior"; Fernando da Costa Ferreira Novo ${ }^{1}$; Rafael de Castro Santana Arouca ${ }^{1}$; Francisco de Salles \\ Collet e Silva, TCBC-SP1; Edna Frasson de Souza Montero,TCBC-SP2; Edivaldo Massazo Utiyama, TCBC-SP²
}

A $B$ S T $T$ R A C T

\begin{abstract}
Objective: to evaluate the outcome of abdominal wall integrity of both techniques. Methods: a retrospective study was carried out at the Hospital das Clínicas, Faculdade de Medicina, Universidade de São Paulo, identifying the patients undergoing temporary abdominal closure (TAC) from January 2005 to December 2011. Data were collected through the review of clinical charts. Inclusion criteria were indication of TAC and survival to definitive abdominal closure. In the post-operative period only a group of three surgeons followed all patients and performed the reoperations. Results:Twenty eightpatients were included. The difference in primary closure rates and mean time for fascial closure did not reach statistical significance $(\mathrm{p}=0.98$ and $p=0.23$, respectively). Conclusion: VAC and Bogota Bag do not differ significantly regarding the outcome of abdominal wall integrity, due to the monitoring of a specific team and the adoption of progressive closure
\end{abstract}

Key words: Peritonitis. Trauma. Sepsis. Negative-Pressure Wound Therapy. Abdominal Wound Closure Techniques. IntraAbdominal Hypertension.

\section{INTRODUCTION}

$M$ ost of the time, at the end performing a laparotomy, the abdomen is closed with primary closure of aponeurosis. However, in some cases, the surgeon is forced to leave the open abdomen tactic that is associated with a mortality rate of $30 \%{ }^{1-3}$.

The open abdomen technique (AA) is a surgical strategy used in patients with related life-threatening intraabdominal hemorrhage, prevention or treatment of intraabdominal hypertension and treatment of intra-abdominal sepsis. It is a temporary measure to prioritize the control of bleeding, correction of metabolic disorders and hypothermia, and facilitate access to the abdominal cavity ${ }^{4}$.

In the 40s, leaving open abdomen after a laparotomy was considered technical failure. However, in the 70, the disseminated abdominal infections represented a major challenge, with mortality rates ranging from $30 \%$ to $80 \%{ }^{5}$. Therefore, at that time, Hay et al. ${ }^{6}$ and Steinberg ${ }^{7}$ proposed to maintain the open abdomen to treat severe peritonitis. In the same period, Champaultet al. ${ }^{8}$ advocated reoperations scheduled for cleaning the abdominal cavity.

Since 1981, the Department of General Surgery and Trauma Hospital of the Faculty of Medicine, Universidade de São Paulo (HCFMUSP), it was established that the open abdomen (AA) with planned reoperations would be an option for the treatment of intra-infections abdominal with systemic repercussions, whose infectious focus could not be removed in one operation'. In the 90's was designed the Damage Control (DC). First described in 1993 by Rotondo et al. as an alternative to final laparotomy in patients with exsanguinantes bleeding related to lesions of large vessels and multiple lesions intra-abdominal viscera ${ }^{10}$. It was later shown to initiate damage control early, before the patient's clinical conditions deteriorate to the extreme [massive blood loss, severe injury (ISS $>$ $25)$, hypothermia $\left(<34^{\circ} \mathrm{C}\right)$, acidosis $(\mathrm{pH}<7.25)$ and blood coagulation (APTT> 19sec)], reduces mortality ${ }^{11}$. Furthermore, keep the cavity open abdominal exposes patients to the risk of perforation of hollow viscera and increases the risk of developing complex hernias. Temporary abdominal closure techniques (FAT) with suture or skin closure Backaus calipers reduce these complications, but increase the risk of abdominal compartment syndrome (ACS). After recognition of morbidity and mortality attributed to SCA, have been developed various methods to avoid this complication ${ }^{12}$.

The ideal technique for the FAT was defined as one that contains the abdominal viscera, limit contamination, prevent the loss of abdominal fluid, avoid adhesions, allow easy access to the abdominal cavity, avoid damage and the retraction of the abdominal wall and stand in the way $\mathrm{ACS}^{13}$.

1. General and Trauma Surgery, Hospital das Clínicas, Medical School at the University of São Paulo, São Paulo, Brazil; 2. Surgery Department of Medical School the University São Paulo. São Paulo, Brazil. 
The application of the Bogota Stock Exchange (BB) has become the most popular and effective method of temporary abdominal closure. It is still used in many hospitals in developing countries because of its low cost and easy handling. It was created by Oswaldo Borráez in 1984 and the name "Bogota bag" was created by Mattox, during a visit to a hospital in Bogota - Colombia, in 199714,15.

A decade ago, the negative pressure application concept was introduced by Barker et al. as a new means of temporary abdominal closure ${ }^{16}$. After the introduction of this vacuum closure technique, a more comprehensive method to manage negative pressure therapy to an open abdominal wound was developed: the closing assisted vacuum, the English "Vacuum Assisted Closure" (VAC). This technique enabled by the possibility of FAT drain peritoneal fluid, to minimize visceral edema, fascial apply greater tension in the abdominal wall and promoting the definitive abdominal closure in patients with open abdomen, one month after the initial laparotomy ${ }^{17,18}$.

Today, despite advances in AA use with the development of vacuum therapy, the Bogota Stock Exchange (BB) is still widely used. In our institution and throughout Brazil, both techniques are used and the study's goal is to evaluate the morbidity and the result of the integrity of the abdominal wall after the use of both techniques.

\section{METHODS}

A retrospective study was conducted at HCFMUSP, identifying patients undergoing temporary abdominal closure (FAT) between January 2005 and December 2011. Data were collected through review of medical records. Data were compared in patients undergoing treatment with assisted closing the vacuum and the Bogota bag.

Inclusion criteria were temporary abdominal closure indication survival and the definitive abdominal closure. FAT indications included: abdominal trauma, severe abdominal sepsis and ACS. Data collected included age, FAT indication, the number of procedures in the operating room and the primary fascial closure rate. In the postoperative period, one group of three surgeons followed all patients and performed all reoperations. As soon as possible, the aponeurosis of the edges were subjected to progressive approach with careful not to cause abdominal hypertension.
The demographics of the two study groups (BB and VAC) were compared using the chi-square test of Pearson or Fisher's exact test for categorical variables and the Student $t$ test for continuous variables.

\section{RESULTS}

During the study period, 59 patients require some kind of temporary abdominal closure (FAT), however, only 29 patients survived the final abdominal closure (52.5\% mortality). One patient was excluded (subject to closure Backaus forceps). Thus, 28 patients were included, and, after two years of follow-up, none of them developed abdominal hernia or intestinal fistulas.

There was no statistical difference between the study groups with respect to age ( $p>0.05)$ and a significant difference regarding indications for temporary abdominal closure $(p<0.05)$ (Table 1).

The primary closure rates were similar in both groups $(p=0.98)$. The average time (days) for fascial closure was 10.8 days for the BB group and 7.52 days in the group VAC (Table 2).

\section{DISCUSSION}

In this study, there was no statistical difference between the closing assisted vacuum and the Bogota bag (VAC and BB) when analyzed the number of operations, the primary closure, and the average time of closing. However, a previous study ${ }^{19}$ showed better results when using VAC BB was compared on the primary closure (50 to $70 \% \%$ and $88 \%$ for $B B$ $V A C)$. The best approach to achieve the definitive abdominal closure in patients with open abdomen remains controversial. To improve the fascial closure rate, the excess volume resuscitation should be avoided, the water balance should be carefully implemented, not only on admission, but also throughout the course of treatment with open abdomen ${ }^{20}$. The high rate of primary closure found in our patients, $80 \%$ for BB and $96 \%$ for the VAC, no statistical difference was due to the above mentioned guidelines and monitoring carried out by the same team of surgeons in all reoperations. This may also explain the same results of other variables analyzed with use of the BB or VAC.

Table 1 - Epidemiological data.

\begin{tabular}{lrrrrr}
\hline & Bogotá $(\mathrm{n}=10)$ & \multicolumn{2}{c}{ VAC $(\mathrm{n}=17)$} & $p$ \\
\hline Average age (years \pm SD) & $39.5 \pm$ & 14.8 & $33.17 \pm$ & 16.6 & 0.17 \\
Trauma & 6 & $(60 \%)$ & 6 & $(35.6 \%)$ & 0.012 \\
Non-trauma & 4 & $(40 \%)$ & 11 & $(64.7 \%)$ & 0.01 \\
\hline
\end{tabular}


Table 2 - Results.

\begin{tabular}{|c|c|c|c|c|}
\hline & Bogotá $(n=10)$ & VAC & $=17)$ & $p$ \\
\hline Average operations & $(1-8)$ & 2.05 & $(1-3)$ & 0.3 \\
\hline Primary closure & $8 \quad(80 \%)$ & 16 & $(94.1 \%)$ & 0.98 \\
\hline Closure average (days \pm SD) & $10.8 \pm 14.46$ & $7.52 \pm$ & 9.03 & 0.23 \\
\hline
\end{tabular}

A major obstacle to the abdominal closure is the retraction of the rectus abdominal muscles, which should be avoided at all costs. While the patient is open abdomen, the fascial edges are placed under tension by interrupted suture with nonabsorbable suture caliber. This strategy avoids the fascial retraction and facilitates the gradual approximation of aponeurotic edges in each reoperation until definitive abdominal closure ${ }^{21}$. These techniques also applied in our patients, reflect the high rate of abdominal closure, and reduced closing average time found that study, even when BB is the chosen method.

Another factor is the indication of the method used to implement the FAT. Some studies have shown the efficiency of the use of VAC in wounds that were not caused by trauma ${ }^{22,23}$, results similar to those found in our study. Differences were found in the temporary abdominal closure indications: the Bogota bag was most appropriate in cases involving trauma, while VAC was more indicated in cases of abdominal sepsis, abdominal compartment syndrome and mesenteric ischemia.

The absence of abdominal hernias and intestinal fistulas in patients undergoing FAT in our service is due to the technique used and the care adopted and applied by the same surgical team.

In our experience, the closing assisted vacuum (VAC) and the Bogota bag do not differ significantly with respect to the result of the integrity of the abdominal wall, although there is a tendency in our institution to use BB preferably in trauma and VAC in cases "no trauma". The monitoring of a specific team and the progressive closure of adoption are the factors that can explain the absence of difference between the groups and the high closing rate of the abdominal wall for both VAC and for the Bogota bag.

\section{R E S U M O}

Objetivo: avaliar o resultado da integridade da parede abdominal após utilização do fechamento assistido a vácuo e da bolsa de Bogotá. Métodos: um estudo retrospectivo foi realizado no Hospital das Clínicas da Faculdade de Medicina da Universidade de São Paulo (HCFMUSP), identificando os pacientes submetidos à técnica de fechamento abdominal temporário (FAT) entre janeiro de 2005 e dezembro de 2011. Os dados foram coletados por meio de revisão de prontuários. Os critérios de inclusão foram indicação de FAT e sobrevivência até o fechamento definitivo da parede abdominal. No período pós-operatório, apenas um grupo de três cirurgiões, seguiu todos os pacientes e realizou as reoperações. Além disso, independente da técnica de FAT utilizada, foi aplicada a tática de fechamento fascial progressivo durante as reoperações. Resultados: Vinte e oito pacientes foram incluídos. Não houve diferença estatística nas taxas de fechamento primário e tempo médio de fechamento fascial. Conclusão: O fechamento assistido a vácuo e a bolsa de Bogotá não diferem significativamente em relação ao resultado da integridade da parede abdominal após as reoperações. Isso se deve ao acompanhamento de uma equipe específica e a adoção de técnica de fechamento fascial progressivo.

Descritores: Peritonite. Trauma. Sepse. Tratamento de Ferimentos com Pressão Negativa. Técnicas de Fechamento de Ferimentos Abdominais. Sindrome Compartimental Abdominal.

\section{REFERENCES}

1. Keremati M, Srivastava A, Sakabu S, Rumbolo P, Smock M, Pollack $J$, et al. The Wittmann Patch is a temporary abdominal closure device after descompressive celiotomy for abdominal compartment syndrome following burn. Burns. 2008;34(4):493-7.

2. Kushimoto S, Miyauchi M, Yokota H, Kawai M. Damage control surgery and open abdominal management: recent advances and our approach. J Nippon Med Sch. 2009;76(6):280-90.

3. Perez A, Hilvano S. Abdominal zippers for temporary abdominal closure in planned relaparotomies for peripancreatic sepsis: experience in a developing country. J Hepatobiliary Pancreat Surg. 2001;8(5):449-52.
4. Schecter WP, Ivatury RR, Rotondo MF, Hirshberg A. Open abdomen after trauma and abdominal sepsis: a strategy for management. J Am Coll Surg. 2006;203(3):390-6.

5. Farthmann EH, Schoffel U. Principles and limitations of operative management of intraabdominal infections. World J Surg. 1990;14(2):210-7.

6. Hay J, Duchatelle P, Elman A, Flamant Y, Maillard JN. Les ventres laissés ouvert. Chirurgie. 1979;105(6):508-10

7. Steinberg D. On leaving the peritoneal cavity open in acute generalized suppurative peritonitis. Am J Surg. 1979;137(2):21620 
8. Champault G, Magnier M, Psalmon F, Patel JC. L'evisceration controlée dans le traitement des peritonites graves. Chirurgie. 1979;105(9):866-9.

9. Utiyama EM, Pflug ARM, Damous SHB, Rodrigues Jr AC, Montero EFS, Birolini CAV. Temporary abdominal closure with zipper-mesh device for management of intra-abdominal sepsis. Rev Col Bras Cir. 2015;42(1). In press.

10. Rotondo MF, Schwab CW, McGonigal MD, Phillips GR 3rd, Fruchterman TM, Kauder DR, et al. 'Damage control': an approach for improved survival in exsanguinating penetrating abdominal injury. J Trauma. 1993;35(3):375-82; discussion 382-3.

11. Hirshberg A, Mattox KL. Planned reoperation for severe trauma. Ann Surg. 1995;222(1):3-8.

12. Offner PJ, de Souza AL, Moore EE, Biffl WL, Franciose RJ, Johnson $\mathrm{JL}$, et al. Avoidance of abdominal compartment syndrome in damage-control laparotomy after trauma. Arch Surg. 2001;136(6):676-81.

13. Stone HH, Strom PR, Mullins RJ. Management of the major coagulopathy with onset during laparotomy. Ann Surg. 1983:197(5):532-5.

14. Borráez OA. Abdomen Abierto: la herida más desafiante. Rev Colomb Cir. 2008;23(4):204-9.

15. Ghimenton F, Thomson SR, Muckart DJ, Burrows R. Abdominal content containment: practicalities and outcome. Br J Surg. 2000:87(1):106-9.

16. Barker DE, Kaufman HJ, Smith LA, Ciraulo DL, Richart CL, Burns RP. Vacuum pack technique of temporary abdominal closure: a 7year experience with 112 patients. J Trauma. 2000;48(2):201'-6; discussion 206-7.

17. Miller PR, Thompson JT, Faler BJ, Meredith JW, Chang MC. Late fascial closure in lieu of ventral hernia: the next step in open abdomen management. J Trauma. 2002;53(5):843-9.
18. Boele van Hensbroek P, Wind J, Dijkgraaf MG, Busch OR, Goslings JC. Temporary closure of the open abdomen: a systematic review on delayed primary fascial closure in patients with an open abdomen. World J Surg. 2009;33(2):199-207.

19. Miller PR, Meredith JW, Johnson JC, Chang MC. Prospective evaluation of vacuum-assisted fascial closure after open abdomen: planned ventral hernia rate is substantially reduced. Ann Surg. 2004;239(5):608-14; discussion 614-6.

20. Goussous N, Kim BD, Jenkins DH, Zielinski MD. Factors affecting primary fascial closure of the open abdomen in the nontrauma patient. Surgery. 2012;152(4):777-83; discussion 783-4

21. Cothren CC, Moore EE, Johnson JL, Moore JB, Burch JM. One hundred percent fascial approximation with sequential abdominal closure of the open abdomen. Am J Surg. 2006;192(2):238-42.

22. Perez D, Wildi S, Demartines N, Bramkamp M, Koehler C, Clavien PA. Prospective evaluation of vacuum-assisted closure in abdominal compartment syndrome and severe abdominal sepsis. J Am Coll Surg. 2007;205(4):586-92.

23. Adkins AL, Robbins J, Villalba M, Bendick P, Shanley CJ. Open abdomen management of intra-abdominal sepsis. Am Surg. 2004;70(2):137-40; discussion 140.

Received on 06/05/2014

Accepted for publication 30/06/2014

Conflict of interest: none.

Source of funding: none.

Address for correspondence:

Edivaldo MassazoUtiyama

E-mail: adilsoncrjr@usp.br 